\title{
FIELD COLLECTING LIVING MATERIAL IN PAPUA, INDONESIA
}

\author{
Sadie Barber ${ }^{1} \&$ Andrew Ensoll ${ }^{2}$
}

\begin{abstract}
This paper sets out 'best practice' methods for field collecting wild material, based on experience gained during a two-month expedition to the Indonesian province of Papua. The horticultural team involved in the trip sought to keep cuttings, rhizomes, seedlings, whole plants, seeds and spores intact and healthy while in the field. With several obstacles including climate and lengthy delays in transportation to deal with, the high success rate of collected material is testament to the careful techniques employed in the processing of living plant material in the field.
\end{abstract}

\section{INTRODUCTION}

Papua - the western half of the island of New Guinea, and part of Indonesia (Fig. 1) - lies just south of the equator. It is the largest island in Indonesia (area of 41.48 million ha), with the lowest population in comparison to other islands of Indonesia. The province is dominated by tropical rainforest and, apart from at its highest elevations, the climate is hot and humid year-round.

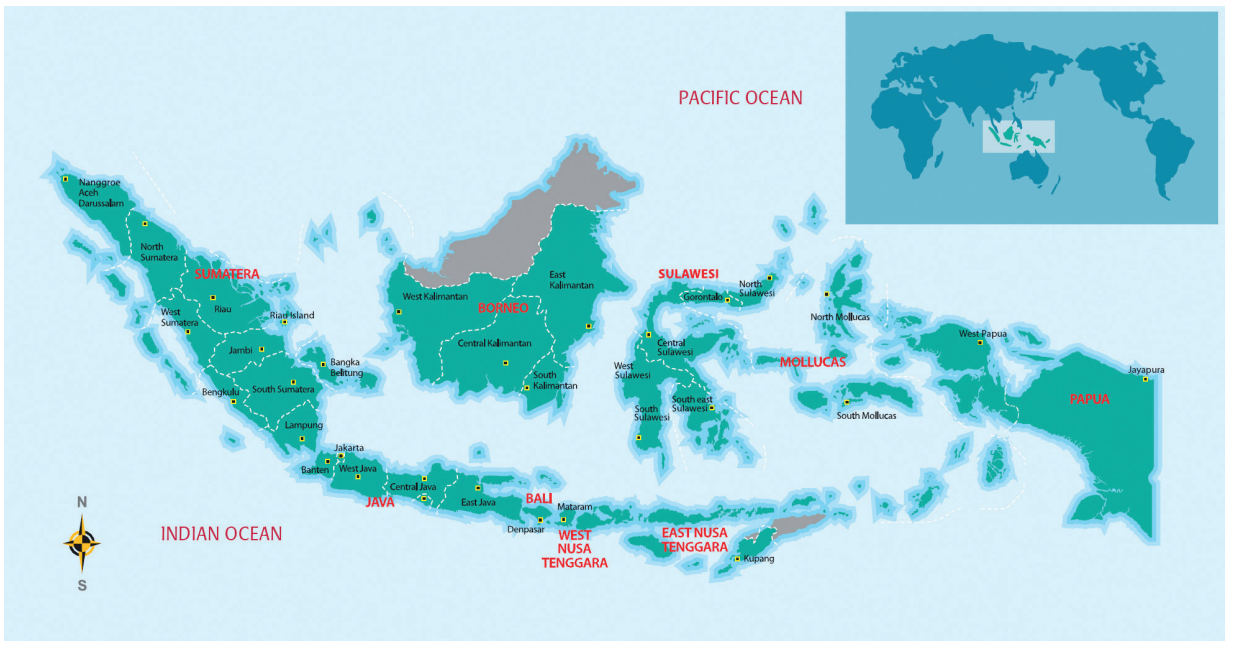

Fig. 1 Island groups that make up the country of Indonesia, with Papua to the east. Image: my-indonesia (2008).

1. Sadie Barber is a Senior Horticulturist in the Research Collection at the Royal Botanic Garden Edinburgh. Address: 20A Inverleith Row, Edinburgh EH3 5LR

Email: s.barber@rbge.org.uk

2. Andrew Ensoll is a Senior Horticulturist in the Research Collection at the Royal Botanic Garden Edinburgh.

Address: 20A Inverleith Row, Edinburgh EH3 5LR

Email: a.ensoll@rbge.org.uk 
It has been incredibly difficult to obtain permission to work in Papua, as well as in some other parts of Indonesia, over the past ten years because of political unrest. After a year's planning and communication with authorities in Indonesia, we were granted all the necessary permissions and, in January 2009, embarked on a two-month collecting trip to one of the world's most biodiverse and unexplored regions. Louise Galloway glasshouse supervisor at Royal Botanic Garden Edinburgh (RBGE) - was team leader, with research associate Dr George Argent, senior horticulturist Andrew Ensoll and junior horticulturist at that time Sadie Barber completing the group (Fig. 2). We were joined by two Indonesian counterparts: Pak Rustandi from Cibodas Botanic Garden, part of the Indonesian Institute of Sciences (LIPI), and Charlie Heatubun, a palm expert from Universitas Negeri Papua.

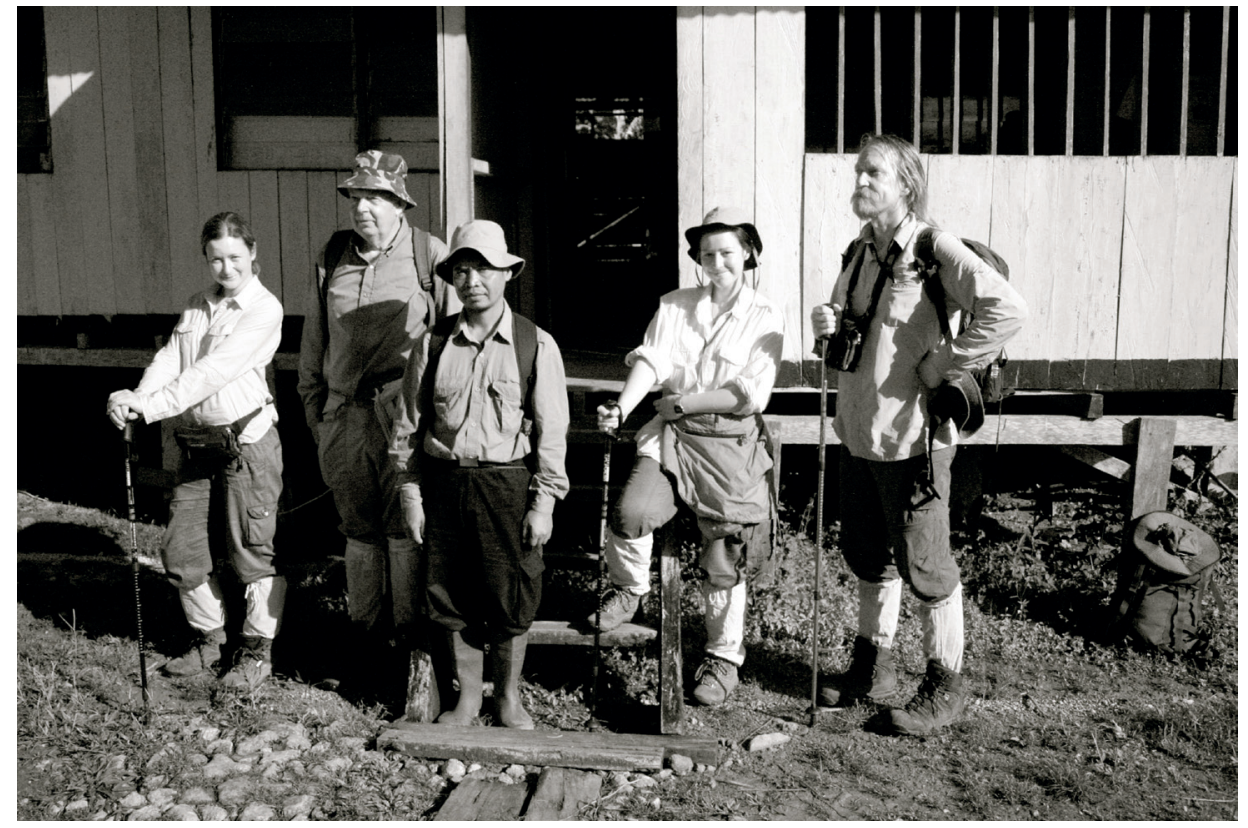

Fig. 2 The Papua expedition team (1-r): Louise Galloway, Dr George Argent, Pak Rustandi, Sadie Barber, Andrew Ensoll. Photo: Charlie Heatubun.

The proposed trip was primarily to the Wissel Lakes (Fig. 3) area in the eastern province of Papua (this province is officially known as 'Papua', and to the west is the 'West Papua' province). We also factored in collecting trips to the Arfak Mountains (Fig. 4), a range in the northern half of West Papua (also known as Vogelkop, or Bird's Head Peninsula), and to Yapen Island as a back-up collecting area. Since 1872, when Italian botanist Odoardo Beccari made the first New Guinea botanical collections in the Arfak Mountains, there have been several plant-collecting expeditions to the Arfak range, as well as to Yapen Island. Arfak in particular has seen a lot of scientific activity and exploration over the years, including a visit by the first independent female explorer in New 
Guinea, Lilian Suzette Gibbs. The only recorded major plant-collecting expedition to the Wissel Lakes (now Paniai Lakes) was in 1939. This expedition was led by botanist P.J. Eyma, and lasted almost a year (Frodin, 2007).

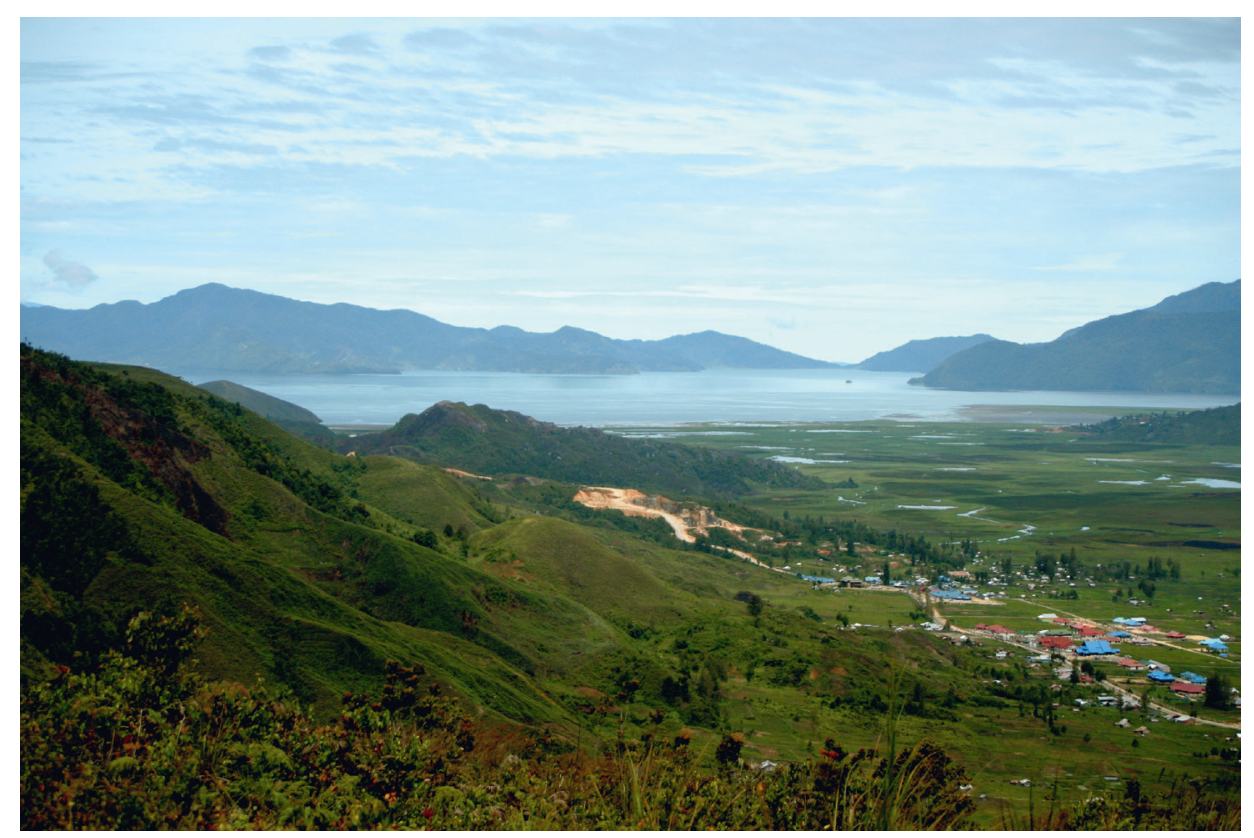

Fig. 3 Lake Paniai, the largest of the Wissel Lakes. Photo: Sadie Barber.

We set out to collect specific plant families, including Begoniaceae, Gesneriaceae, Ericaceae, Zingiberaceae, Musaceae and Sapotaceae, as well as any Pteridophytes and Gymnosperms (consisting of several families). It is noted in The Ecology of Papua (Takeuchi, 2007) that the island of New Guinea (which is Papua and Papua New Guinea combined) is thought to possess nearly 30 per cent of the world's fern diversity, with an estimated 3,000 species. This richness of pteridophytes in the Papuan rainforest was immediately apparent on arrival, and the collection of ferns was to become a main focus of our expedition.

\section{COLLECTING}

As this was a horticulturally led expedition, we aimed to collect a large amount of living material. The best possible way to do this is to collect seed and spores; this material is less bulky, may have more variation in the progeny, can result in more plants for display and research, is less likely to carry disease, can be imported without quarantine and may be less damaging to the ecology of the habitat.

However, seeds and spores are not always present, and this was largely the case for seed plants because of the season in which we visited. Also, some ferns such as Marattia 
sp. can only grow with mycorrhizal associations and so are difficult to grow from spores without a symbiotic culture. In these cases collections of living plants were made as oracles or sporelings. In the end a large proportion of our living collections were made as cuttings, seedlings, sporelings or rhizomes.

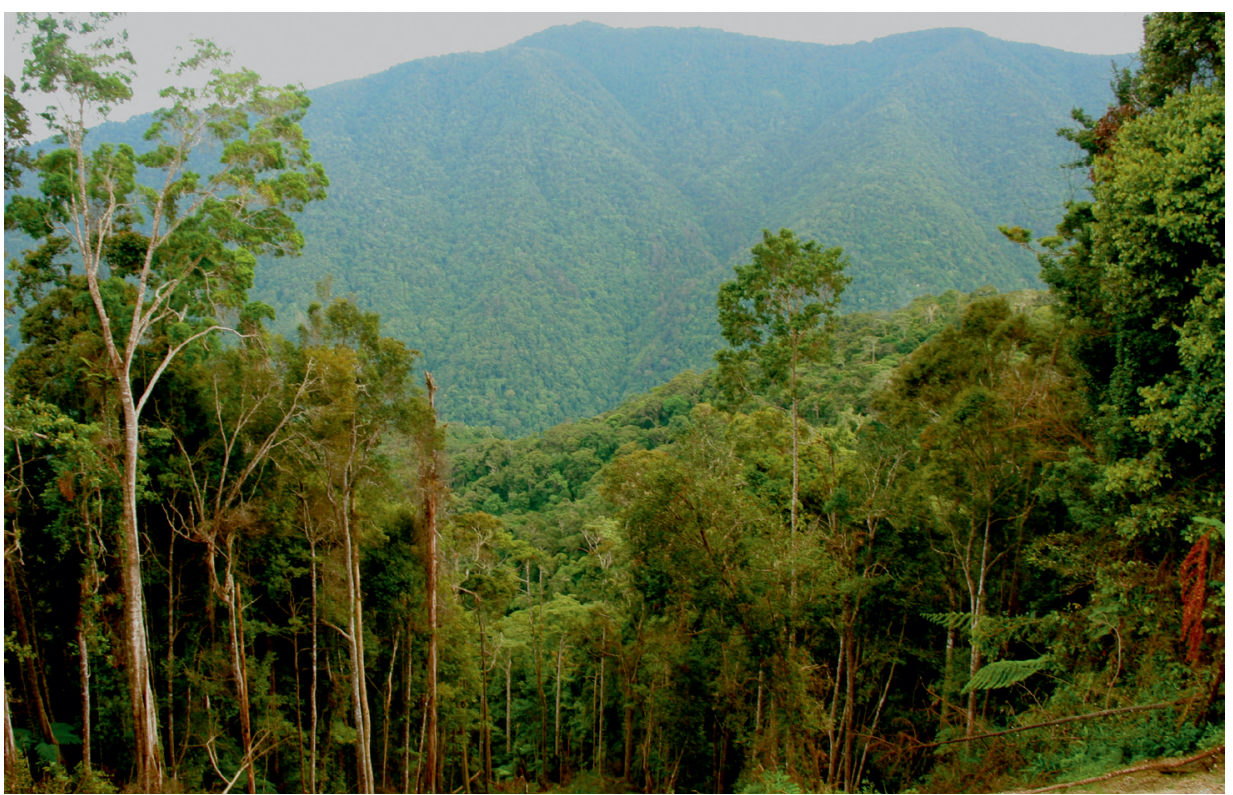

Fig. 4 A view from one of the Arfak Mountain roads; the location of the first collection. Photo: Sadie Barber.

A typical collection would be carried out as follows:

When a plant of interest is found, it is given the next successive collecting number which is preceded by the letters ABEG, the acronym given for the names Argent, Barber, Ensoll and Galloway. This same number will be used for any type of specimen, be it seed, cutting or a herbarium specimen collected from the plant. A photograph is taken of the whole plant (Fig. 5), plus any distinguishing features such as flower, fruit, form, and so on. In some cases, a grey card will also be photographed. This is a simple technique used by professional photographers to achieve consistent exposures. In our case, Sadie Barber set the ISO and aperture of the camera and noted the adjustment in shutter speed to

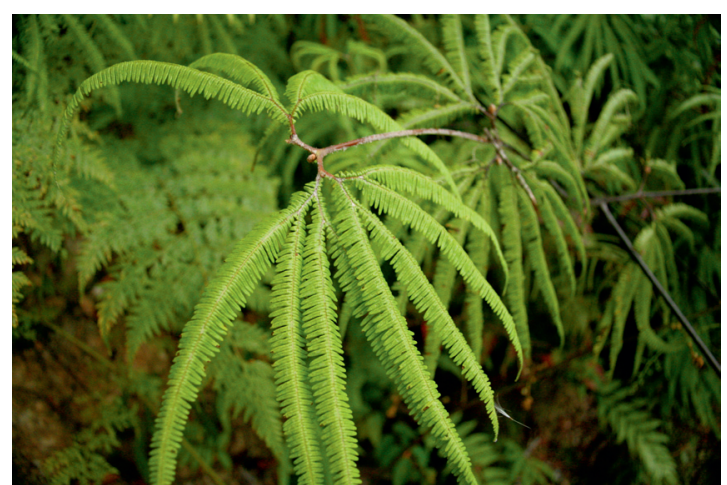

Fig. 5 Sticherus sp., a member of the family Gleicheniceae; collection ABEG 1. Photo: Sadie Barber. 
reach the correct exposure. The calculations from these readings give an indication of the relative light intensity under which the plant was growing.

Next, field notes are taken (Fig. 6). A complete field description will include:

- collection number

- date

- location

- name of plant

- type of specimen collected:

H herbarium

PT whole plant

SG seedling

$\mathbf{S}$ seed

CT cutting

RH rhizome

SP spore

D dna

- description of plant

- GPS waypoint

- altitude

- description of habitat type, for example 'primary rainforest with closed canopy'

- other associated plant species

- description of soil, aspect, slope

- any additional notes such as local name

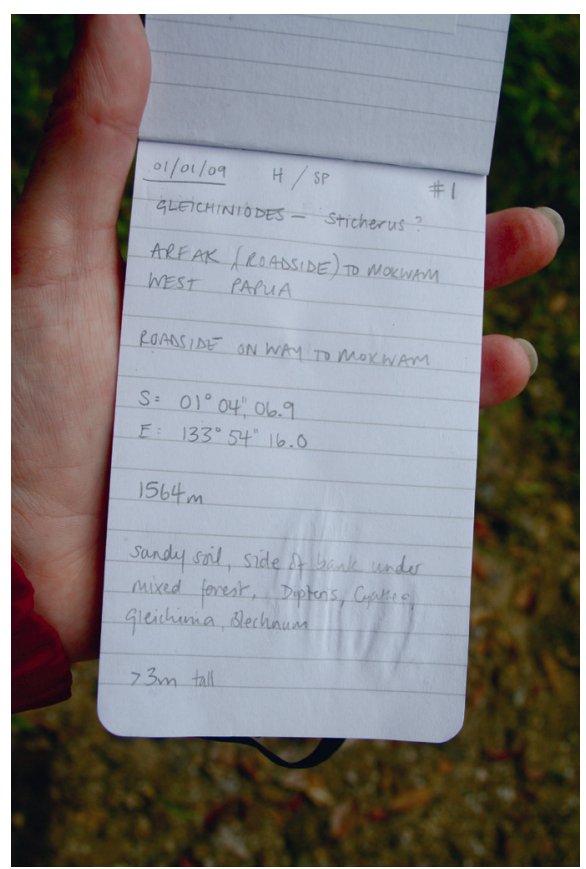

Fig. 6 Field collection notes. Photo: Sadie Barber. or local uses for plant.

The ideal collection would be a herbarium specimen coupled with ripe seed or spores and rhizomes or cuttings as a secondary, or back-up, collection. Every one of these parts would have the same collecting number, all relating back to the original wild plant from which they were collected.

\section{SEEDS AND SPORES}

The seeds and spores were collected in botanical envelopes (Fig. 7), or small Ziploc ${ }^{\circledR}$ bags in the case of potentially recalcitrant species such as Zingiberaceae. A description of these envelopes is given in Barber \& Scott (2009). Written on these envelopes and bags was the collection number, which referred to the detailed information in the collection notebooks.

Botanical envelopes are invaluable in the field as they can be folded and sealed without the need for glue or adhesive and can be made out of any type of paper available 


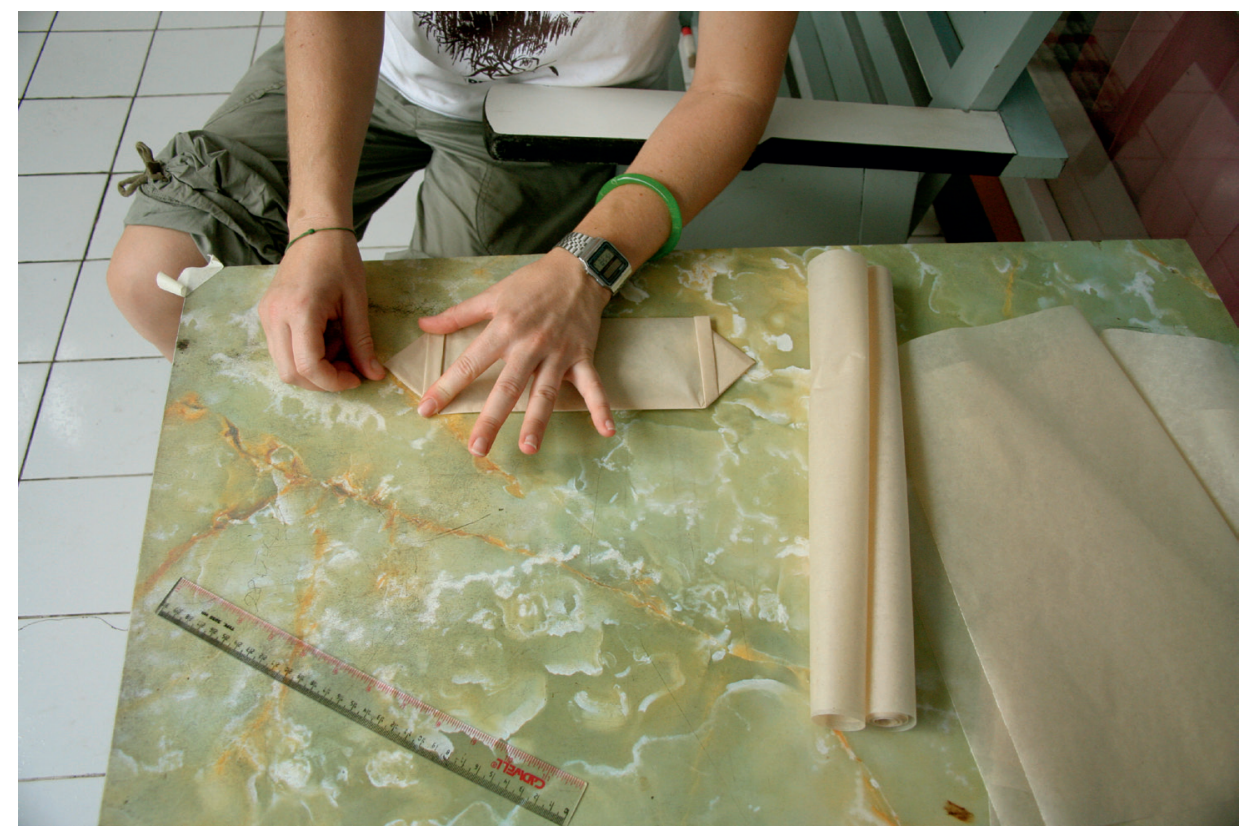

Fig. 7 Louise folds botanical envelopes ready to go into the field. Photo: Sadie Barber.

(although we have found that greaseproof paper is optimal because of its thinness, strength and versatility).

Ideally, mature seed pods or fruits are collected, but these can take time to find on a plant. If there are only unripe seeds present, they can still be collected with the hope that they will ripen if left in a bag. In this case cuttings would also usually be taken as a second collection.

Fleshy fruits were placed in plastic bags and either cleaned and transferred to dry envelopes or sealed and kept moist. This is for seeds that are potentially recalcitrant, or unripe and requiring further development (Fig. 8).

Examples of fleshy-fruited species collected included Leea sp., Drimys sp., Vaccinium sp., Alocasia sp. and members of the Zingiberaceae family (Fig. 9). These seeds were regularly checked for any rot but also kept slightly moist with damp tissue or moss.

Some seeds, such as Rhododendron species in the group Vireya, need to be kept as dry as possible, as they only remain viable for two to six months. This can be very difficult in the hot, humid conditions of tropical rainforests. 


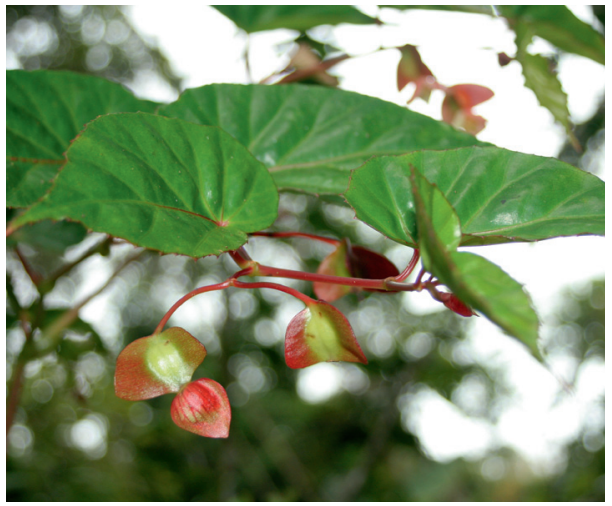

Fig. 8 Unripe seed pods of Begonia sp. Photo: Sadie Barber.

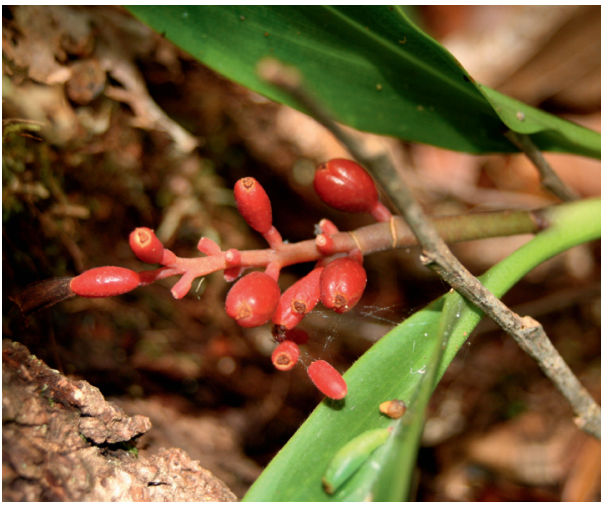

Fig. 9 Fleshy seeds of a Zingiberaceae collection. Photo: Sadie Barber.

When collecting spores, it is important to be able to identify which material is ripe. Often, a fern frond has a range of spores present, from immature to ripe, or shed within the sporangia. Comparing them is often a good way to ascertain which are mature (Fig. 10). When no mature spores are obviously present, a collection of shed spore fronds can be made and usually some spores will be found trapped in the sporangia.
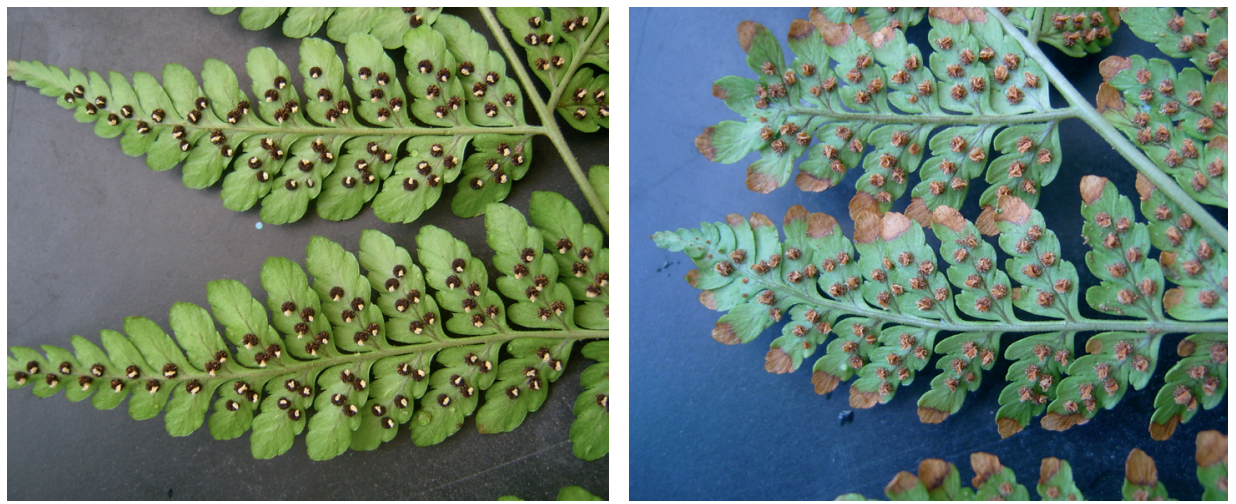

Fig. 10 Healthy, mature spores (1); spores have shed (r). Photos: Sadie Barber.

As with any collection, it is important to find the cleanest, healthiest of material. The fronds can be cut or stripped to fit into the envelope but it is important not to overfill the envelope so as to allow the frond to dry and spores to shed.

Some ferns produce green spores, such as those of Hymenophyllaceae and Osmundaceae. These spores have a very short viability under normal conditions (only two to seven days), but if they are maintained in a moist condition they can remain viable for a much longer period. Fronds with the green spores can be kept moist on damp tissue in a sealed bag and should be kept as cool as possible. 


\section{COLLECTING LIVING MATERIALS}

For the collection of optimal material in the field, the following guidelines were used:

- Always use clean and sharp blades

- Transfer to bags quickly to avoid wilting (Fig. 11)

- Take large cuttings of more mature material; these can be reduced in size later

- Make clean cuts, being careful not to bruise the material or the parent plant

- Choose pest-free and disease-free healthy material; by using strong healthy material there is more chance of survival

- Select healthy seedlings and plants

- Handle plants and roots carefully

- Wrap roots in damp moss or tissue to avoid dehydration

- When collecting seedlings from a group, choose those that are easy to extract to ensure there is no damage to either plant or environment

- Rhizomes should be a good size

- Reduce aerial stems to fit into bags

- Select non-flowering material

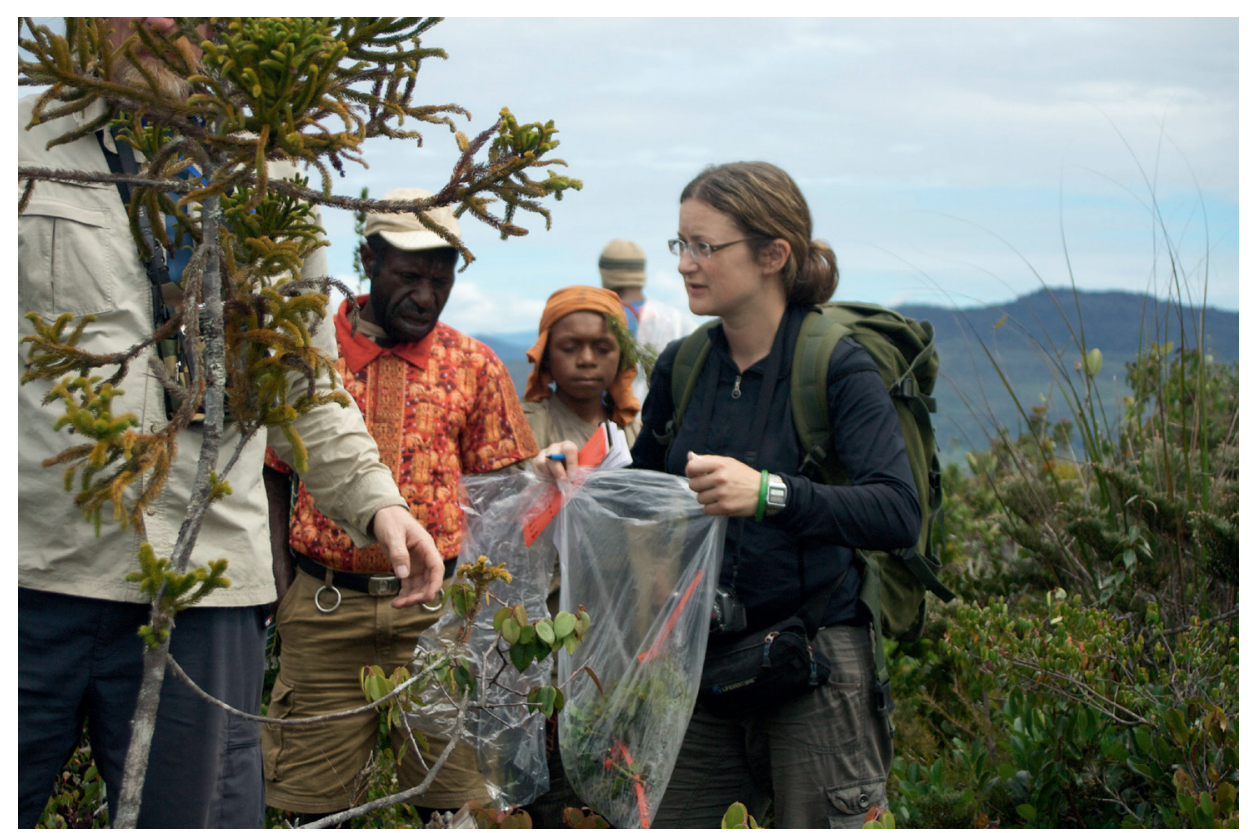

Fig. 11 Cuttings were labelled and placed in large plastic bags. Photo: Sadie Barber.

For collecting living material in the field we used large plastic bags and labels; the plant material was carefully carried in the bags and we took care not to lose the specimens' labels (rubber bands can be used to attach labels; Fig. 12). 
A trowel was used to dig up rhizomes or to divide plants. It is important to keep the bags out of sunlight so that the material doesn't get too hot. Plant material can be sprayed with water if it begins to dry out.

Smaller material such as liverworts were placed directly into a small Ziploc ${ }^{\circledR}$ bag with either damp tissue or moss. With experience, we concluded that damp tissue is preferable to moss, since the latter can contain hidden pests and diseases.

When back at base camp, the plants are processed; the collection bags are always kept out of sunlight in a cool position. The plants were kept in the bag and sprayed with a mister when needed, and only one plant was taken out at a time for processing.

Cuttings: When collecting cuttings, the number of leaves is reduced, leaving a clean stem base. Larger leaves are also cut down in size to reduce transpiration and to take up less space in the container. The stem may also be cut down in size. Any damaged plant parts are cut away.

The base of the stem is wrapped in tissue, which is then moistened and the cutting is placed in a small Ziploc ${ }^{\circledR}$ bag (Fig. 13). An elastic band is used to hold the bag round the stem bases. At least one label is attached to the plants, on a stem, and sometimes also on the elastic band.

It is of the utmost importance to keep the plants with their corresponding labels. The cuttings, when prepared, are placed in a clean plastic 'rice' box and the lid placed on while the next plant is processed (Fig. 14).

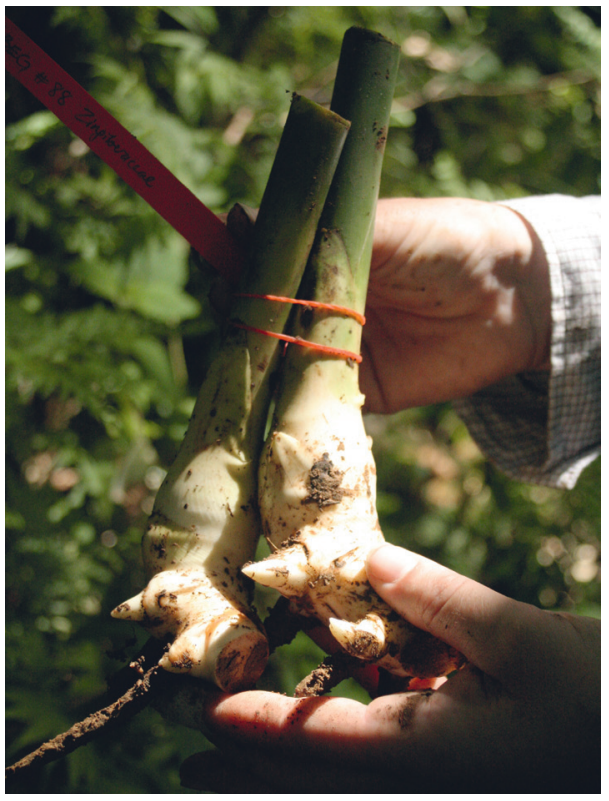

Fig. 12 A healthy Zingiberaceae rhizome is dug up and the label attached with rubber bands. Photo: Sadie Barber.

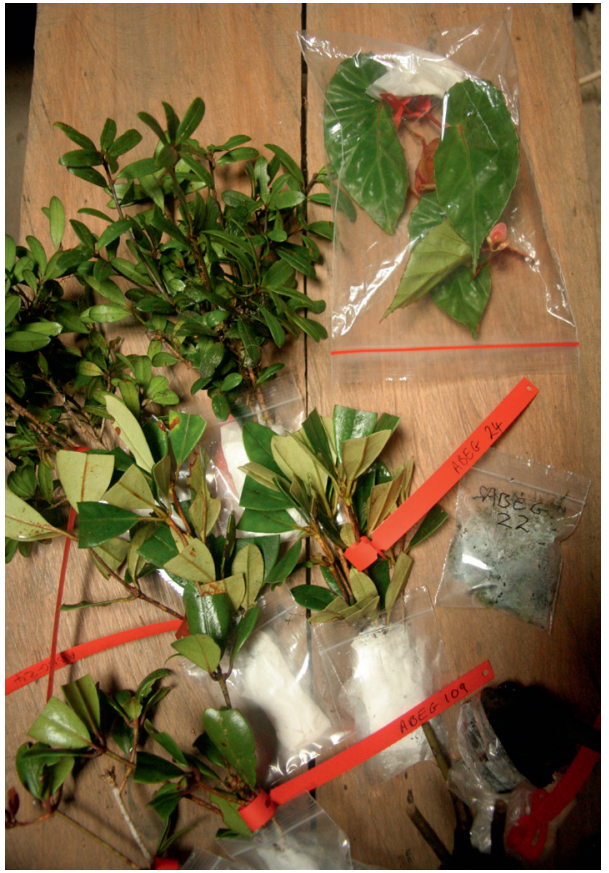

Fig. 13 Cuttings are prepared and labelled. Photo: Sadie Barber. 


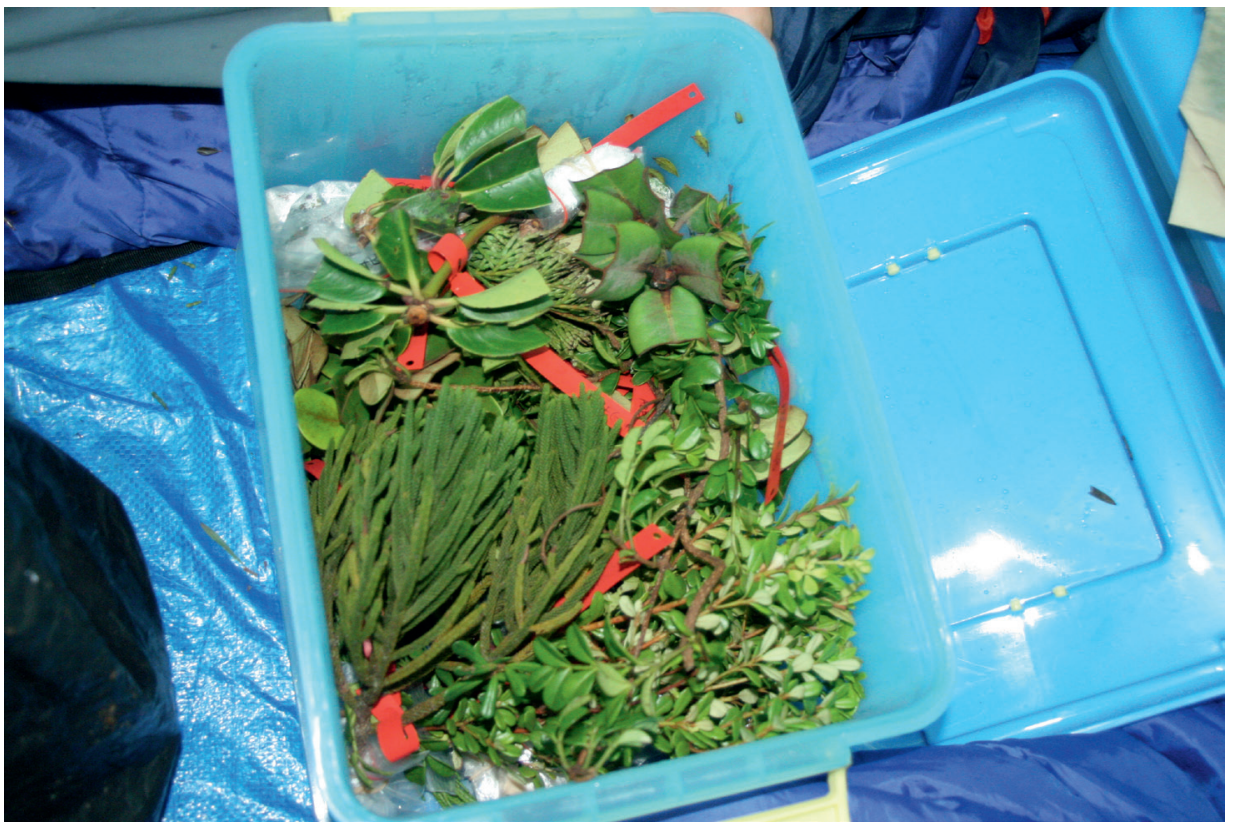

Fig. 14 A plastic 'rice' box, used to hold the cuttings, seedlings and whole plants. Photo: Sadie Barber.

Seedlings and plants: A similar process to that for cuttings is followed; the material is cleaned and checked for any pests, particularly any that may be in the soil accompanying the plant. The roots and only a small portion of the plant are wrapped in tissue and the same procedure followed. It is important not to wrap any growing points because the moisture and lack of air may cause rot.

Rhizomes: Roots are wrapped, leaving any growing points exposed. Cuts are cleaned and shoots reduced. The rhizome is then wrapped and elastic bands are usually used in this instance to hold the plastic bag in place. The material is then kept and maintained in these closed plastic boxes, which are also used for transporting the plants to new locations.

It was critical to keep the boxes out of the sun, and in as cool conditions as possible (Fig. 15). Air-conditioned hotel rooms were a godsend! Every few days the plants were taken out of the boxes and checked. Any dead material was removed, and the box was cleaned. Any dry tissue was remoistened.

Trying to keep a stable atmosphere was a balancing act - not too dry, not too wet, not too hot or cold. Even with a lot of care and attention some plants did not tolerate the closed damp environment of the box. An example was Schefflera monticola, which was found growing at about $2,000 \mathrm{~m}$ in relatively dry, bright, open conditions. Plants found growing in the damper forest under-storey showed greater tolerance to these closed conditions. 
It was also critical that the boxes were not overfilled and that the more delicate, softer material was not squashed. Heavy rhizomes and tough conifers were placed at the bottom of the box with soft plants such as begonias and those in the family Gesneriaceae on top.

\section{CONCLUSION}

A total of 330 plants were collected. Some of these plants were collected as multiple specimens (herbarium and living) and the final numbers are shown in Table 1:

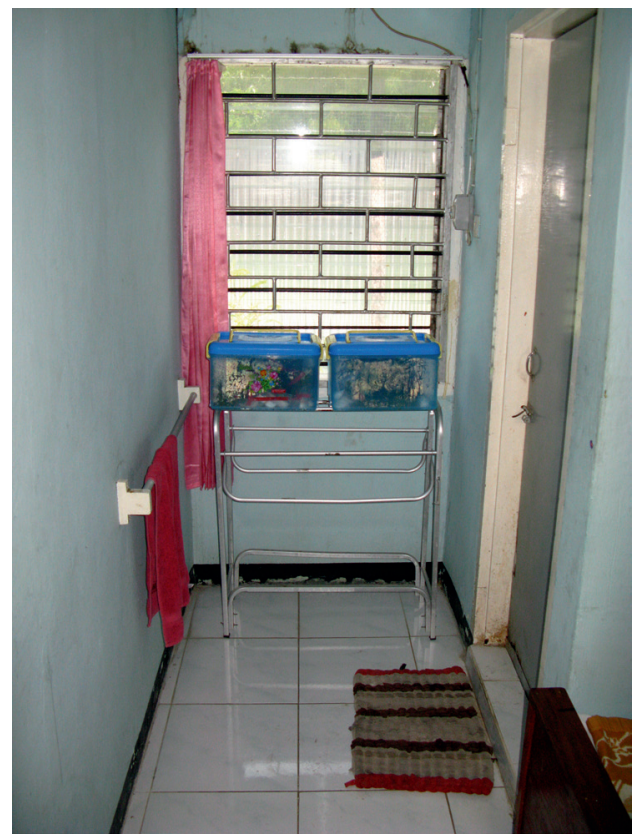

Fig. 15 The rice boxes, kept in the shade and under air-conditioning. Photo: Andrew Ensoll.

\begin{tabular}{|l|c|}
\hline \multicolumn{1}{|c|}{ Type of specimen collected } & \multicolumn{1}{c|}{ Number collected } \\
\hline Herbarium & 87 \\
\hline Cuttings & 96 \\
\hline Spores & 84 \\
\hline Whole plants & 72 \\
\hline Seeds & 52 \\
\hline Seedlings & 10 \\
\hline Rhizomes & 2 \\
\hline DNA & 3 \\
\hline Total & 406 \\
\hline
\end{tabular}

Table 1 A breakdown of the specimens taken from the 330 plants collected.

The total consisted of 90 'sterile' (DNA and herbarium) and 316 'living' specimens.

Most of the Living Collection survived remarkably well over the six weeks that we were in the field, with a few exceptions. Some cuttings and rhizomes even started to produce roots. The dry spores and seeds remained quite stable. The material that was kept entirely in Ziplocs ${ }^{\circledR}$, such as the fleshy seeds, had also survived well. Unfortunately, because of a change in the regulations, we were unable to complete our export permit and bring the material back to RBGE on our return. 
We had no choice but to leave our spore and seed packets in an air-conditioned office at Bogor Botanic Garden which lies $80 \mathrm{~km}$ south of Jakarta and instruct staff at the Cibodas Botanic Garden, which lies $120 \mathrm{~km}$ south of Jakarta, to build a polythene cloche (Fig. 16) to house all of our cuttings, seedlings and rhizomes. The plants were potted up with their labels (bunches of cuttings were kept together). They were sprayed and the soil kept moist (Fig. 17).

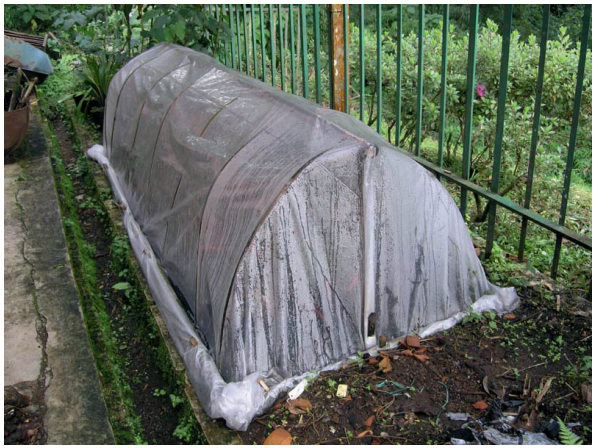

Fig. 16 The plastic cloche, constructed by staff at Cibodas Botanic Garden, following our design. Photo: Rismita Sari.

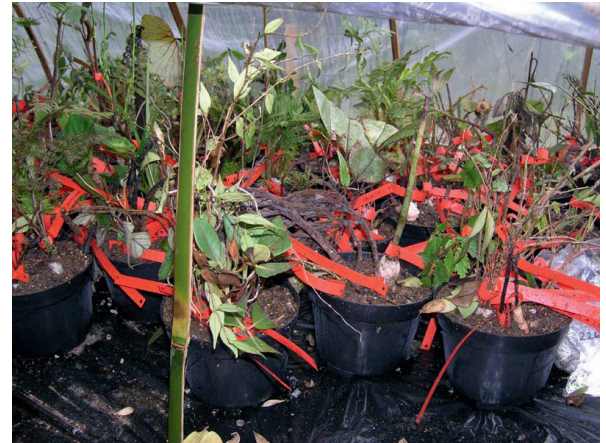

Fig. 17 Cuttings grouped together and potted in the cloche at Cibodas Botanic Garden. Photo: Rismita Sari.

On our return to Edinburgh without our plants, in a fit of desperation we sowed the film of dry mud from leech socks, boots, backpacks and Thermarests ${ }^{\circledR}$. From this, we were surprised to find a large germination of higher plants and ferns. We successfully germinated a total of six higher plant seeds (Fig. 18), including grasses, Asteraceae and Lamiaceae species, and spores of 19 fern species (Fig. 19).

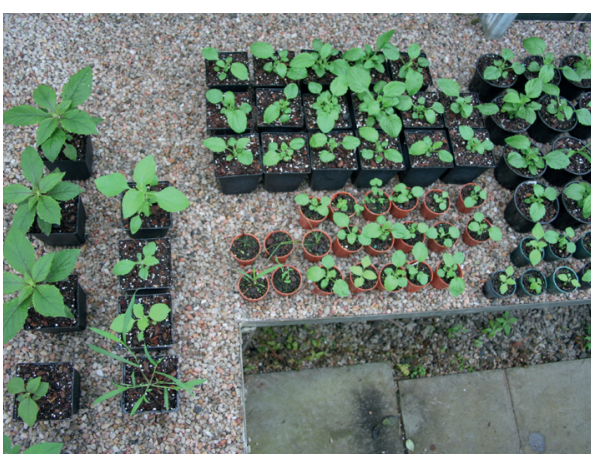

Fig. 18 Selection of higher plants germinated from seeds found in dry mud. Photo: Sadie Barber.

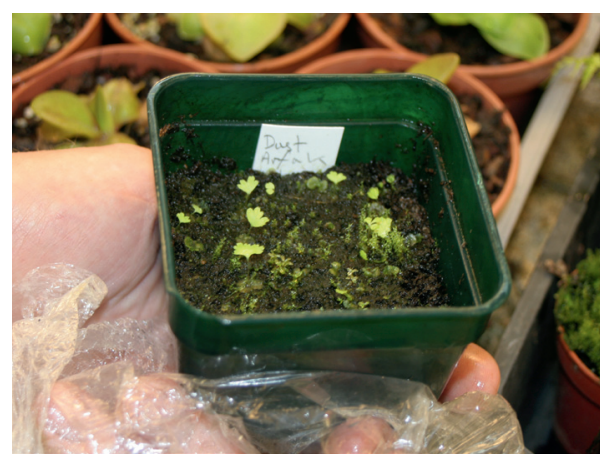

Fig. 19 Germination of ferns from spores found in dry mud. Photo: Sadie Barber.

It took two months for the plants to be released from Indonesia, and we asked staff at Cibodas Botanic Garden to rewrap the material and pack it all as we had done previously. With such a long delay we had expected the worst with regard to the health 
of the plants. Happily, about three-quarters of the living material (cuttings, seedlings, rhizomes and whole plants) survived, some of it very well. This living material went into quarantine, where it was inspected and then potted (Figs 20 and 21).

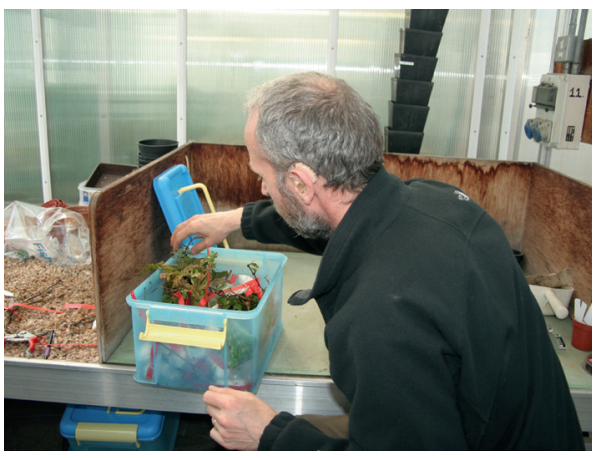

Fig. 20 Stefan Helfer inspects the material upon arrival at the quarantine house at RBGE. Photo: Sadie Barber.

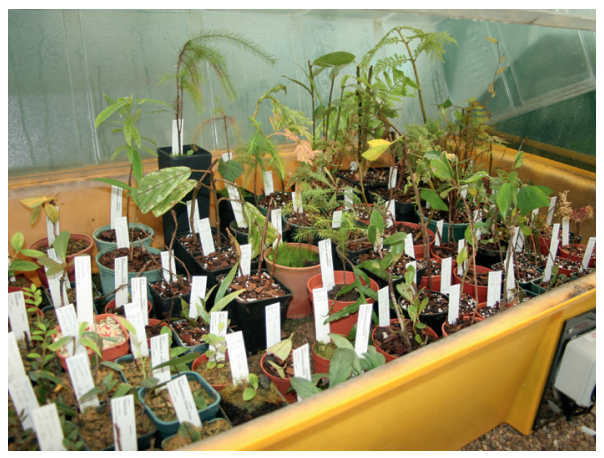

Fig. 21 Some of the potted cuttings, seedlings, rhizomes and whole plants in a quarantine case. Photo: Sadie Barber.

The seed and spore collections were all sown, although some of the fleshy seeds, many in family Zingiberaceae, had rotted and did not germinate. Most of the spores were successfully germinated (Fig. 22) but some with a much reduced percentage of germination. Those that have not germinated included those species belonging to the Gleicheniaceae family, suggesting that the spores of this family may be short-lived. A

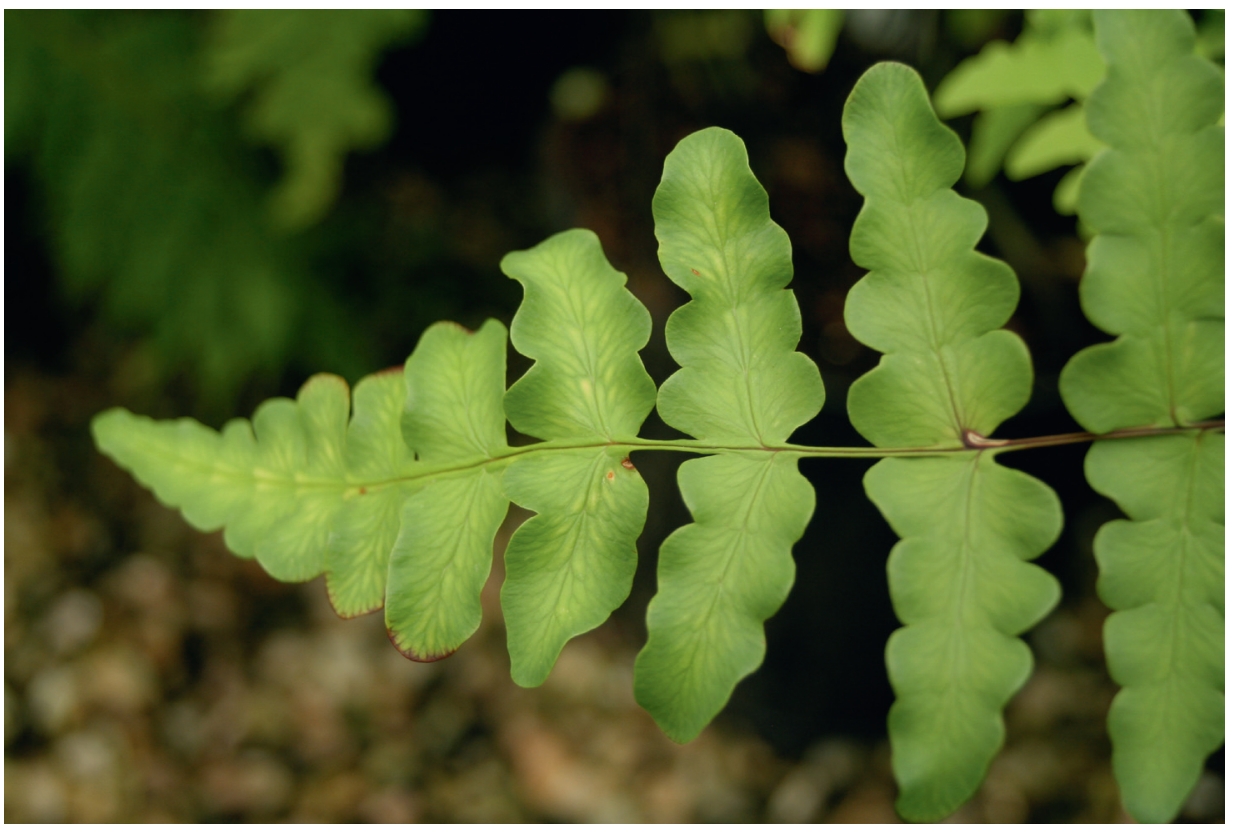

Fig. 22 One of the successfully germinated ferns Histiopteris incisa. Photo: Sadie Barber. 
collection of Alocasia seeds in a Ziploc ${ }^{\circledR}$ bag had in fact germinated before reaching Edinburgh, and these have been grown on successfully.

Now, 14 months after the arrival of the material to RBGE, there are several species awaiting identification - these include angiosperms yet to produce flowers, or pteridophytes yet to spore. Of the 316 living collections made, 238 are now in the Living Collection (42 of which are still in quarantine); this number equates to a success rate of just over 75 per cent. In addition, with every seed or spore sowing, more ferns often germinate. These are sometimes associated species that have been collected nearby and have resulted from spores from adjacent plants lodging on the species being collected. The ABEG numbers may increase further still!

\section{REFERENCES}

BARBER, S. \& SCOTT, S. (2009). Short Note: Botanical Envelopes. Sibbaldia, 7, 197-200.

FRODIN, D.G. (2007). Biological exploration of New Guinea, in MARSHALL, A.J. \& BEEHLER, B.M. (eds). The Ecology of Indonesia Series, Volume VI: The Ecology of Papua. Periplus Editions (HK) Ltd., Singapore, 14-107.

MY-INDONESIA (2008). Indonesia overview map. Available online: http://mappery.com/ Indonesia-Overview-map (accessed May 2010).

TAKEUCHI, W.N. (2007). Introduction to the flora of Papua, in MARSHALL, A.J. \& BEEHLER, B.M. (eds). The Ecology of Indonesia Series, Volume VI: The Ecology of Papua. Periplus Editions (HK) Ltd., Singapore, 269-302. 